\title{
Penerapan Teknologi Pembelajaran Dalam Meningkatkan Kemampuan Warga Belajar Dalam Menangulangi Penularan Covid-19 Pada Penyelenggaraan Pendidikan Nonformal
}

\author{
Rudi Amir ${ }^{1}$, M. Ali Latif Amri ${ }^{2}$, Fatmawati Gaffar ${ }^{3}$ \\ Jurusan Pendidikan Luar sekolah, Fakultas Ilmu Pendidikan, Universitas Negeri Makassar \\ rudiamir@unm.ac.id
}

\begin{abstract}
ABSTRAK
Penelitian ini mengkaji tentang penerapan teknologi pembelajaran yang terdiri dari pemanfaatan sumber belajar dan media pembelajaran berbasis teknologi dalam meningkatkan kemampuan warga Belajar dalam menanggulangi penularan Covid-19 pada program pendidikan nonformal di Kabupaten Takalar, Gowa, dan Maros. Tujuan dari penelitian ini adalah untuk mengetahui berbagai jenis Sumber belajar dan media pembelajaran berbasis teknologi yang sering digunakan oleh tutor dan seberapa besar pengaruhnya terhadap kemampuan warga belajar dalam menaggulangi penularan covid-19. Populasi dalam penelitian ini sebanyak 100 Warga Belajar dan yang menjadi sampel penelitian sebanyak 30 Orang dengan menggunakan teknik random sampling. Teknik analisis data penelitian yang digunakan adalah teknik deskriptif kuantitatif dan regresi sederhana. Berdasarkan hasil penelitian terdapat pengaruh yang signifikan penerapan teknologi pembelajaran dalam meningkatkan kemampuan warga belajar dalam menaggulangi penularan covid-19.
\end{abstract}

Kata kunci: Sumber belajar, Media Pembelajaran

\section{ABSTRACT}

This study examines the application of learning technology which consists of the use of learning resources and technology-based learning media in improving the ability of learning citizens to cope with Covid-19 transmission in non-formal education programs in Takalar, Gowa, and Maros districts. The purpose of this research is to find out the various types of learning resources and technology-based learning media that are often used by tutors and how much influence they have on the ability of learning citizens to tackle covid-19 transmission. The population in this study were 100 study citizens and the sample of the study were 30 people using random sampling techniques. The research data analysis technique used is descriptive quantitative technique and simple regression. Based on the results of the study, there is a significant effect of the application of learning technology in increasing the ability of learning citizens to tackle covid-19 transmission.

Keywords: Learning Resources, Learning Media

\section{PENDAHULUAN}

Dewasa ini perkembangan dan kemajuan teknolgi informasi berjalan sangat cepat. Seiring dengan perkembangan teknologi informasi, penyimpanan dan pengiriman data semakin murah dan semakin baik kualitasnya.Baik individu, institusi, maupun pemerintah ikut melakukan berbagai upaya untuk memanfaatkan perkembangan teknologi informasi ini. Bahkan dalam dunia pendidikan di Indonesia, sudah saatnya kita memanfaatkan teknologi informasi tersebut. Apalagi dengan adanya program school net, jardiknas dan sebagainya, maka seluruh komponen lembaga pendidikan dituntut menyiapkan diri dengan menyiapkan sarana prasarana untuk memanfaatkan perkembangan teknologi informasi tersebut. Teknologi informasi ini memberikan nilai tambah dalam proses pembelajaran.Hal ini berkaitan dengan semakin tingginya kebutuhan informasi ilmu pengetahuan dan teknologi yang tidak semuanya diperoleh dalam lingkungan sekolah. Demikian pula pada saat melakukan pertukaran data dan informasi antar sekolah, sekolah dengan masyarakat, sekolah dengan pemerintah daerah dan pusat, dan lain-lain, semuanya akan lebih efektif dan efisien jika memanfaatkan teknologi informasi.

Di era global ini semakin banyak perkembangan teknologi yang sudah dimanfaatkan di berbagai bidang salah satunya adalah di dunia pendidikan. Karena teknologi tidak luput dari peran pendidikan yang harus ditekankan. Selain itu pendidikan sangat penting bagi kita maka dari pada itu tujuan dari 
pembahasan tentang perkembangan teknologi di dunia pendidikan adalah agar para siswa ataupun pembaca bisa memahami bagaimana hubungan antara pendidikan dan teknologi yang semula teknologi berasal dari pendidikan itu sendiri. Bayak hal yang merubah proses ataupun pembuatan dalam menjalankan sesuatu dari yang asalnya sangat sederhana menjadi lebih mudah itulah yang dinamankan perubahan teknologi. Begitu juga dengan pendidikan yang pada awalnya belum tahu setelah mempelajarinya menjadi tahu. Selain itu agar siswa bisa mengerti dan memahami lebih mendalam tentang teknologi dan menggunakan teknologi untuk menunjang pendidikan itu sendiri.

Penerapan teknologi dalam dunia pendidikan merupakan suatu hal yang tidak bisa lagi elakkan, malahan sudah menjadi suatu kebutuhan. Keberadaan teknologi sangat membantu peserta didik dalam belajar, mereka lebih banyak memiliki sumber informasi yang diperoleh melalui teknologi komunikasi dan informasi. Demikian pula pendidik, mereka lebih mudah memperoleh bahan pembelajaran dengan mengakses bahan tersebut melalui internet serta dapat memudahkan pendidikan dalam menyampaikan materi kepada peserta didik melalui penerapan teknologi pembelajaran.

Penyelenggaraan pendidikan nonformal sebagai amanah yang tertuang dalam Undangundang sistem pendidikan nasioanl nomor 20 tahun 2003 merupakan salah satu jalur pendidikan yang dapat ditempuh oleh warga masyarakat yang memerlukan layanan pendidikan yang berfungsi sebagai pengganti, penambah, dan/atau pelengkap pendidikan formal, yang berfungsi mengembangkan potensi peserta didik dengan penekanan pada penguasaan pengetahuan dan keterampilan fungsional serta pengembangan sikap dan kepribadian profesional. Penyelenggaraan pendidikan nonformal dapat berbentuk pendidikan kecakapan hidup, pendidikan anak usia dini, pendidikan kepemudaan, pendidikan pemberdayaan perempuan, pendidikan keaksaraan, pendidikan keterampilan dan pelatihan kerja, pendidikan kesetaraan, serta pendidikan lain yang ditujukan untuk mengembangkan kemampuan peserta didik.

Untuk memaksimalkan penyelenggaraan pendidikan nonformal, sangat diperlukan adanya penerapan teknologi pendidikan.

Dalam penyelenggaraan pendidikan nonformal, teknologi berfungsi sebagai alat, dalam hal ini TIK digunakan sebagai alat bantu bagi pengguna atau peserta didik untuk membantu pembelajaran, misalnya dalam mengolah kata, mengolah angka, membuat unsur grafis, membuat database, membuat program administratif untuk peserta didik, guru dan staf, data kepegawaian, keuangan dan sebagainya. Teknologi juga berfungsi sebagai bahan dan alat bantu untuk pembelajaran (iteracy). Dalam hal ini teknologi dimaknai sebagai bahan pembelajaran sekaligus sebagai alat bantu untuk menguasai sebuah kompetensi berbantuan komputer. Dalam hal ini komputer telah diprogram sedemikian rupa sehingga siswa dibimbing secara bertahap dengan menggunakan prinsip pembelajaran tuntas untuk menguasai kompetensi. Dalam hal ini posisi teknologi tidak ubahnya sebagai guru yang berfungsi sebagai: fasilitator, motivator, transmiter, dan evaluator.

Oleh karena itu, tidak bisa lagi dipungkiri bahwa untuk mengefektifkan terjadinya interaksi pembelajaran pada penyelenggaraan pendidikan nonformal, maka penerapan teknologi sangatlah diperlukan. Salah satu kabupaten yang aktif menyelenggarakan pendidikan nonformal adalah Kabupaten Takalar, dimana pendidikan nonformal diselenggarakan oleh beberapa lembaga pendidikan yang khusus menyelenggarakan pendidikan nonformal seperti Satuan Pendidikan Nonformal Sanggar Kegiatan Belajar (SPNF-SKB) Kabupaten Takalar dan beberapa Pusat Kegiatan Belajar Masyarakat. jenis pendidikan yang diselenggarakan oleh lembaga tersebut adalah pendidikan keaksaraan Paket $\mathrm{A}$, paket $\mathrm{B}$, dan paket $\mathrm{C}$, pendidikan kusrsus dan pelatihan, serta pendidikan keaksaraan.

Pengelenggaraan pendidikan nonformal yang dilasanakan oleh lembaga pemerintah maupun swasta atau masyarakat telah memanfaatkan teknologi di dalam proses pembelajaran, baik yang sifatnya sangat sederhana sampai yang bersifatnya sangat canggih.

Berdasarkan Latar belakang tersebut di atas, maka dirumuskan masalah sebagai berikut:

1. Bagaimana pemanfaatan sumber belajar berbasis teknologi dalam pengelenggaran pendidikan nonformal di Kabupaten Takalar, Gowa, dan Maros?

2. Bagaimana pemanfaatan media pembelajaran berbasis teknologi dalam penyelenggaran pendidikan nonformal di Kabupaten takalar Gowa, dan Maros? 


\section{Kawasan Teknologi Pembelajaran.}

Rumusan kawasan teknologi pembelajaran memiliki ruang lingkup yang lebih sempit dalam dunia pendidikan dibandingkan dengan kawasan Teknologi pendidikan. Kawasan teknologi pembelajaran tetap merujuk pada learning is purposive and controlled. Pernyataan ini menjelaskan kedudukan kawasan teknologi pembelajaran adalah di kelas. Sumber belajar berperan langsung sebagai komponen sistem pembelajaran. Sumber belajar dalam kawasan teknologi pembelajaran sengaja dirancang (by design) sesuai dengan ungkapan istilah prestructured dan dimanfaatkan atau utilized. Sumber belajar harus memenuhi kriteria sebagai berikut: (a) dirancangdimanfaatkan yang disiapkan khusus yang berlandaskan kompetensi dan materi ajar; (b) dipilih-dimanfaatkan yang sesuai dengan kompetensi dan materi ajar dari koleksi yang sudah tersedia di sekolah (Prawiradilaga, 2012: 45).

Definisi AECT tahun 1994 hanya menelurkan satu definisi yaitu teknologi pembelajaran, kawasan yang dimunculkan pun hanya satu yaitu kawasan teknologi pembelajaran. Namun dalam penjelasannya, definisi tersebut berhasil memilah antara teori dan praktik. Teori yang disebut sebagai rujukan dan acuan dari seluruh kegiatan terkait pembelajaran, sedangkan praktik atau terapan menyediakan kesempatan untuk memvalidasi teori, selanjutnya teori ini dapat dikaji ulang dan diperbaiki. Dengan demikian, terjadi simbiosis mutualisme antara peran teori bagi terapan atau praktik dalam bidang teknologi pembelajaran.

Proses dalam kawasan definisi ini adalah pekerjaan yang tidak ada titik, atau tidak berhenti. Proses dilakukan terus-menerus, seperti lingkaran. Proses sebagai pola pemikiran menelusuri sesuatu hal terkait satu dengan yang lain. Sedangkan sumber yang digunakan dari definisi mewakili produk yang dapat ditawarkan oleh teknologi pembelajaran. Produk ini terkait dengan kebendaan yang dihasilkan teknologi pembelajaran sebagai bidang garapan.

Pengertian sumber belajar adalah suatu sistem yang terdiri dari sekumpulan bahan atau situasi yang diciptakan dengan sengaja dan dibuat agar memungkinkan peserta didik belajar secara individual. Menurut Nana Sudjana dan Ahmad R. sumber belajar itu adalah daya yang bisa dimanfaatkan guna kepentingan proses belajar mengajar, baik secara langsung maupun secara tidak langsung, sebagian atau secara keseluruhan. Menurut Wina Sanjaya sumber belajar adalah segala sesuatu yang dapat dimanfaatkan oleh siswa untuk mempelajari bahan dan pengalaman belajar sesuai dengan tujuan yang hendak dicapai.

Maka dapat disimpulkan bahwa sumber belajar adalah merupakan segala sesuatu yang berupa sekumpulan bahan dan dapat dimanfaatkan dalam kepentingan proses belajar mengajar untuk memperoleh informasi dan pengalaman, sehingga dapat mempermudah aktivitas belajar. Sumber belajar dapat berasal dari lingkungan sekitar tempat tinggal peserta didik atau sengaja dibuat sebagai sumber belajar yang berasal dari lingkungan langsung misalnya, manusia, gunung, laut, candi, hutan dan sebagainya, sedangkan yang sengaja dibuat sebagai sumber belajar adalah buku, video, diorama, museum, laboratorium dan sebagainya.

\section{Jenis-Jenis Sumber Belajar}

a. Pesan (message), adalah informasi pembelajaran yang disampaikan yang dapat berupa ide, fakta, ajaran, nilai dan data. Pesan adalah informasi pembelajaran yang disampaikan yang dapat berupa ide, fakta, ajaran nilai dan data.

b. Orang (people), adalah manusia yang berperan sebagai pencari, penyimpan, pengolah, dan penyaji pesan. Contohnya guru, dosen, tutor, pustakawan, laboran, instruktur, widyaiswara, pelatih olah raga, tenaga ahli, produser, peneliti dan masih banyak lagi, bahkan termasuk peserta didik itu sendiri.

c. Bahan adalah merupakan perangkat lunak (software) yang mengandung pesan-pesan pembelajaran yang biasanya disajikan melalui peralatan tertentu. Contohnya, buku teks, modul, transparansi (OHT), kaset program audio, kaset program video, program slide suara, programmed instruction, CAI (pembelajaran berbasis komputer), film dan lain-lain.

d. Alat adalah perangkat keras (hardware) yang digunakan untuk menyajikan pesan yang tersimpan dalam bahan. Contohnya, OHP, proyektor slide, tape recorder, video/CD player, komputer, proyektor film dan lain-lain.

e. Teknik adalah prosedur atau langkah-langkah tertentu yang disiapkan dalam menggunakan bahan, alat, lingkungan dan orang untuk menyampaikan pesan. Misalnya demonstrasi, diskusi, praktikum, pembelajaran mandiri, sistem pendidikan terbuka/jarak jauh, tutorial tatap muka dan sebagainya. 
f. Latar/lingkungan adalah situasi di sekitar terjadinya proses pembelajaran tempat peserta didik menerima pesan pembelajaran. Lingkungan dibedakan menjadi dua macam, yaitu lingkungan fisik dan lingkungan non fisik. Lingkungan fisik contohnya, gedung sekolah, perpustakaan, laboratorium, aula, bengkel dan lain-lain. Sedangkan lingkungan non fisik contohnya, tata ruang belajar, ventilasi udara, cuaca, suasana, lingkungan belajar dan lainlain.

g. Digital Library (DL)

TIK dewasa ini memunculkan sumber belajar yang dapat membantu proses pembelajaran yaitu, Digital Library (DL) yang bermanfaat sebagai sistem pendukung yang menyediakan materi pembelajaran. Peserta didik melakukan pencarian sumber belajar dengan digital library sebagai modal untuk membentuk pengetahuan baru Berdasarkan kesepakatan Dlib Working Group on Digital Library Metrics di Stanford University, mendefinisikan "Digital Library is the collection of services and the collection of information objects that support users in dealing with information objects and the organization and presentation of those objects available directly or indirectly via electronic digital means" Digital Library adalah sebuah sistem informasi yang menyediakan layanan untuk mengakses koleksi informasi secara langsung atau tidak langsung melalui alat elektronik atau dalam format digital.Perpustakaan Digital adalah sebuah sistem yang memiliki layanan dan obyek informasi yang mendukung akses obyek informasi tersebut melalui perangkat digital. Layanan ini diharapkan dapat mempermudah pencarian informasi di dalam koleksi obyektif informasi seperti dokumen, gambar, database dalam format digital dengan cepat, tepat, dan akurat.

\section{METODE PENELITIAN}

Jenis penelitian ini tergolong ke dalam penelitian kuantitatif, dengan setting penelitian menggambarkan situasi dan kondisi (ketersediaan dan kelengkapan media pembelajaran serta pemanfaatannya dalam pembelajaran). Penelitian deskriptif dirancang untuk memeroleh informasi/data tentang status gejala pada saat penelitian dilakukan (Furchan, 1982: 415). Peneliti mengidentifikasi/mendata pemanfaatan sumber belajar dan media pembelajaran berbasis teknologi dalam penyelenggaraan pendidikan nonformal di Kabupaten Takalar, Gowa dan Maros. Populasi penelitian ini adalah Warga belajar Pendidikan Kesetaraan paket C Pendidikan Nonformal yang ada di Satuan Pendidikan Nonformal Sanggar Kegiatan Belajar Kabupaten Takalar, Gowa dan Maros yang terdiri dari 100 orang. Adapun sampel dari penelitian ini sebanyak 30 $\%$ dari seluruh jumlah populasi, sehingga diperoleh sampel sebesar 30 orang dengan menggunakan teknik random sampling.

\section{HASIL \& PEMBAHASAN}

Berdasarkan hasil uji normalitas diketahui nilai signifikansi $0,366>0,355$ nilai $r$ tabel dengan taraf signifikansi 0,05 , maka dapat disimpulkan bahwa nilai residual berdistribusi normal.

\section{Statistik Deskriptif}

Jumlah data yang dinyata valid sebanyak 15 item dengan jumlah populasi sebanyak 31 orang. Range (jangkauan) menyatakan selisih dari nilai maksimum dengan nilai minimum item 1 yaitu 2.00 dengan nilai minimum 3.00 dan maksimum 5.00. Range dari item Item 2, 3 $5,9,10,11,14$, dan 15 yaitu 4.00 dengan nilai minimum 1.00 dan maksimum 5.00. Range dari item $4,6,7,8,12,13$ yaitu 3,00 dengan nilai minimum 2.00 dan maksimum 5.00. nilai ratarata (mean) sebesar 3\% sampai dengan 4\%.

\section{Regresi Sederhana dan Uji T}

Tabel ANOVA, dari tabel itu pada kolom Sig. diperoleh nilai $\mathrm{P}$ (P-value) $=0,09$. Dengan demikian pada taraf nyata $=0,05$ kita menolak Ho, sehingga kesimpulan yang didapatkan adalah ada pengaruh pemanfaatan media sebagai sumber belajar terhadap pencegahan penularan virus corona.

Tabel 1. Perhitungan Anova

\section{Coefficients $^{\mathrm{a}}$}

\begin{tabular}{|c|c|c|c|c|c|c|}
\hline & \multirow[t]{2}{*}{ Model } & \multicolumn{2}{|c|}{$\begin{array}{l}\text { Unstandardized } \\
\text { Coefficients }\end{array}$} & \multirow{2}{*}{$\begin{array}{c}\begin{array}{c}\text { Standardized } \\
\text { Coefficients }\end{array} \\
\text { Beta } \\
\end{array}$} & \multirow[t]{2}{*}{$\mathrm{t}$} & \multirow[t]{2}{*}{ Sig. } \\
\hline & & B & Std. Error & & & \\
\hline \multirow[t]{2}{*}{1} & (Constant) & 2.836 & 17.127 & & .166 & .870 \\
\hline & $\begin{array}{l}\text { Pemanfaatan media } \\
\text { sebagai sumber belajar }\end{array}$ & .802 & .285 & .463 & 2.810 & .009 \\
\hline
\end{tabular}

a. Dependent Variable: pencegahan penularan virus corona 


\section{Pembahasan}

1. Pemanfaatan media sebagai sumber belajar Dalam pemanfaatannya suatu media pembelajaran harus disesuaikan dengan materi pembelajaran sehingga dapat membantu kegiatan belajar peserta didik dan dapat digunakan sesuai dengan kebutuhan guru dalam penyampaian materi ajar. Media pembelajaran diharapkan dapat memperjelas suatu materi pembelajaran sehingga menjadi konkrit dan mudah dipahami peserta didik. Maka media pembelajaran dikembangkan dengan memperhatikan karakteristik media yang akan digunakan sesuai dengan kemampuan peserta didik dan tujuan pembelajaran. Dengan demikian, pembelajaran menjadi efisien dan tujuan pembelajaran dapat tercapai

Menurut Agus S. Suryobroto (2001: 9), pemanfaatan media adalah penggunaan sumber-sumber belajar secara sistematis. Keputusan untuk mencoba atau menggunakan sumber-sumber belajar harus memperhatikan karakteristik peserta didik dan tujuan belajar. pemanfaatan ini membidangi tentang bagaiman secara teori dan praktek suatu proses dan sumber belajar dimanfaatkan untuk kepentingan belajar. Kawasan pemanfaatan ini terdiri dari pemakaian media, penyebaran media, implementasi dan pelembagaan serta kebijaksanaan dan peraturan.

Penelitian ini bertujuan untuk mengetahui pemanfaatan media sebagai sumber belajar dalam pembelajaran pendidikan kesetaraan pada satuan pendidikan nonformal dan informal (SPNF)/SKB Propinsi Sulawesi Selatana berdasarkan faktor; (1) Media berbasis visual, (2) Media berbasis audio, (3) Media berbasis audio visual dan (4) Media berbasis komputer. Berdasarkan hasil analisis data statististik deskriptif menunjukkan bahwa Jumlah data yang dinyata valid sebanyak 15 item dengan jumlah populasi sebanyak 31 orang. Range (jangkauan) menyatakan selisih dari nilai maksimum dengan nilai minimum item 1 yaitu 2.00 dengan nilai minimum 3.00 dan maksimum 5.00. Range dari item Item 2, 3 $5,9,10,11,14$, dan 15 yaitu 4.00 dengan nilai minimum 1.00 dan maksimum 5.00. Range dari item $4,6,7,8,12,13$ yaitu 3,00 dengan nilai minimum 2.00 dan maksimum 5.00. Nilai ratarata (mean) sebesar 3\% sampai dengan 4\%. Pemanfaatan media sebagai sumber belajar dalam program pendidikan kesetaraan dalam kategori baik karena dapat menciptakan situasi pembelajaran yang efektif.
Hal ini sesuai dengan pendapat yang dikemukakan oleh Hamalik (2008:49) bahwa fungsi media pembelajaran yaitu: 1) untuk membuat situasi belajar yang efektif, 2) media merupakan bagian integral dalam sistem pembelajaran, 3) media pembelajaran penting untuk mencapai tujuan pemebelajaran, 4) media pembelajaran untuk mempercepat proses belajar mengajar dan membantu siswa untuk memahami materi di dalam kelas, 5) media pembelajaran untuk mempertinggi mutu pendidikan. Media sangat berguna dan bermanfaat pada proses jalannya pendidikan karena dengan media pembelajaran proses pembelajaran lebih terarah, termanage, teratur dan mempunyai pedoman sesuai tujuan pendidikan.

Pemanfaatan media sebagai sumber belajar dalam pembelajaran pendidikan kesetaraan pada satuan pendidikan nonformal dan informal (SPNF)/SKB Propinsi Sulawesi Selatan berdasarkan faktor media berbasis visual masuk dalam kategori sedang. Dari hasil pengambilan data diketahui bahwa seluruh peserta didik telah menggunakan media gambar dalam pembelajaran teori di kelas. Akan tetapi ada beberapa tutor yang tidak menggunakan media gambar pada saat pembelajaran praktek.

Berdasarkan faktor media berbasis audio masuk dalam kategori sedang. Dari hasil pengambilan data diketahui bahwa seluruh peserta didik menggunakan media berbasis audio untuk mengiringi gerakan senam. Tetapi banyak pula peserta didik yang tidak menggunakan media berbasis audio untuk mengikuti instruksi tutor. Faktor media berbasis audio visual masuk dalam kategori sedang. Dari hasil pengambilan data diketahui bahwa seluruh peserta didik menggunakan media video pada saat pembelajaran teori di kelas dan menggunakan media video untuk memperjelas materi yang diajarkan. Tetapi banyak peserta didik yang tidak menggunakan media berbasis audio visual untuk mengatasi keterbatasan waktu dan jumlah tutor. Sedangkan Pemanfaatan media pembelajaran berdasarkan faktor media berbasis komputer masuk dalam kategori sedang. Dari hasil pengambilan data diketahui bahwa ada beberapa peserta didik yang menggunakan Power Point dalam pembelajaran teori di kelas. Hal ini ditujukan agar peserta didik lebih mudah memahami dan mudah dipelajari oleh peserta didik lainnya. Tutor menggunakan Media Power Point untuk menampilkan gambar alat peraga dalam pembelajaran pendidikan kesetaraan 
2. Pengaruh pemanfaatan media sebagai sumber belajar dalam upaya pencegahan penularan covid -19

Sumber belajar adalah segala sesuatu baik yang ada diluar diri peserta didik berupa perangkat materi yang sengaja diciptakan dengan maksud untuk memberikan kesempatan dan kemudahan kepada peserta didik dalam memperoleh sejumlah informasi, pengetahuan, pengalaman, dan keterampilan, dalam proses belajar mengajar. Menurut Mulyasa (2000:48) pengertian sumber belajar adalah segala sesuatu yang dapat memberikan kemudahan kepada peserta didik dalam memperoleh sejumlah informasi, pengetahuan, pengalaman, dan keterampilan, dalam proses belajar mengajar.

Berdasarkan hasil analisis data yang dilakukan, diketahui bahwa pemanfaatan media sebagai sumber belajar yang dinyatakan sebagai variabel $X$ dan pencegahan penularan covid -19 sebagai variabel Y. Data diolah melalui beberapa tahapan yaitu uji validitas dan reliabilitas, uji normalitas data, statistic deskriptif frekuensi serta regresi linear sederhana. Pada uji validitas nilai yang diperoleh setiap item $>$ dari nilai $r$ tabel 355 dengan taraf signifikansi 0,05 yang menyatakan item 1-9 dinyatakan valid. Uji reliablitas variabel $\mathrm{X}$ nilai $\mathrm{r}$ hitung $>\mathrm{r}$ tabel $5 \%$, yaitu $0.657>0.355$, sehingga data tersebut adalah reliabel atau dapat dipercaya dan konsisten. Sedangkan variabel $\mathrm{Y}$ nilai $\mathrm{r}$ hitung $>\mathrm{r}$ tabel $5 \%$, yaitu $0.880>0.355$, sehingga data tersebut adalah reliabel atau dapat dipercaya dan konsisten.

Sedangkan hasil uji normalitas data diketahui nilai signifikansi $0,366>0,355$ nilai $r$ tabel dengan taraf signifikansi 0,05 yang menandakan bahwa nilai residual berdistribusi normal. Kemudian tabel ANOVA, dari tabel itu pada kolom Sig. diperoleh nilai $\mathrm{P}(\mathrm{P}$-value $)=$ 0,09 . Dengan demikian pada taraf nyata $>0,05$ kita menolak Ho, sehingga pemanfaatan media sebagai sumber belajar berpengaruh secara signifikan terhadap pencegahan penularan virus corona.

Hasil penelitian tersebut memberikan informasi bahwa kegiatan belajar memerlukan interaksi dan media sebagai sumber belajar yang merupakan bahagian dari fasilitas belajar. Hasil belajar yang maksimal dapat diperoleh jika kadar interaksi itu tinggi. Adanya media yang dapat dimanfaatkan sebagai sumber belajar mempunyai nilai dalam proses belajar mengajar. Nilai sumber belajar dalam proses belajar mengajar adalah: a. Memperjelas dan mengkonkritkan pemahaman peserta didik tentang konsep yang dipelajari. b. Dapat membuat pemahaman peserta didik lebih tepat dan cepat dan tidak segera dilupakan. 3 . Menimbulkan rasa ingin tahu pada peserta didik dan mengembangkan minat belajar mereka. 4 . Membuat situasi belajar bervariasi dan tidak membosankan. 5. Dapat membantu guru mengefektifkan penggunaan metode mengajar yang dipilih.

Hal ini sesuai dengan pendapat yang dikemukakan oleh Wiratmojo,P dan Sasonohardjo (2002) pemakaian media pembelajaran dalam proses belajar mengajar dapat membangkitkan minat dan keinginan yang baru, membangkitkan motivasi dan rangsangan kegiatan belajar, dan bahkan membawa pengaruh-pengaruh psikologis terhadap pebelajar. Penggunaan media pembelajaran pada tahap orientasi pengajaran akan sangat membantu keefektifan proses pembelajaran dan penyampaian pesan dan isi pelajaran pada saat itu.

Pendayagunaan media sebagai sumber belajar memiliki arti yang sangat penting, selain melengkapi, memelihara, dan memperkaya khazanah belajar, sumber belajar juga dapat meningkatkan aktivitas dan kreativitas belajar, yang sangat menguntungkan baik bagi guru maupun bagi para peserta didik. Dengan didayagunakannya sumber belajar secara maksimal, dimungkinkan orang yang belajar menggali berbagai ilmu pengetahuan yang sesuai dengan bidangnya, sehingga pengetahuannya senantiasa aktual, serta mampu mengikuti akselerasi teknologi dan seni yang senantiasa berubah. Pemanfaatan beragam sumber belajar yang sesuai dengan masingmasing komponen sistem intruksional dan makin menyatu dengan komponen-komponen tersebut, maka hasil belajar yang diperoleh peserta didik makin baik.

\section{KESIMPULAN \& SARAN}

Berdasarkan hasil analisi data yang dilakukan, maka kesimpulan dalam penelitian ini adalah sebagai berikut:

1. Teknologi pembelajaran berupa media audio, audio visual, media cetak serta media online sering dimanfaatkan oleh warga belajar dalam menyerap berbagai informasi dan sekaligus sebagai media pembelajaran yang utama pada masa pandemic Covid-19, seperti bagaimana memilih masker yang standar untuk kesehatan, menjaga jarak aman dari orang lain, menghindari kerumunan dan cara mencuci tangan yang benar. 
2. Teknologi pembelajaran pengaruhnya terhadap kemampuan warga belajar dalam mencegah penularan Covid-19 sangat signifikan dengan disiplinnya warga belajar dalam mematuhi protokol kesehatan setiap aktivitas yang dilakukan sehari-hari

Pengetatan protocol kesehatan sangat penting dilakukan oleh warga belajar pada diri dan keluarga serta masyarakat sekitar, sebab penularan covid-19 hanya dapat diminimalisir dengan adanya pengetatan protocol kesehatan yang dilakukan secara bersama-sama oleh setiap elemen masyarakat. Untuk itu warga belajar sebaiknya ikut berpartisipasi sebagai relawan mengkapanyekan pentingnya menjaga protokol kesehatan dengan memanfaatkan teknologi komunikasi dan informasi yang sifatnya mudah dan cepat diakses diakses oleh masyarakat luas.

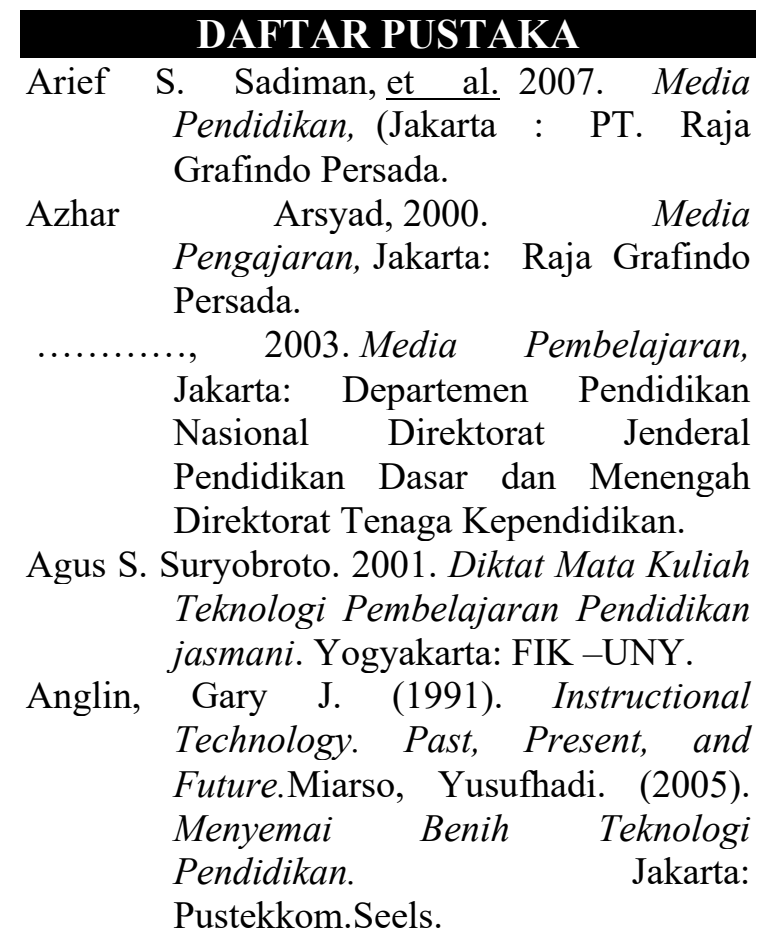

Barbara B. Richey Rita C. (1994). Instructional Technology: The Definition and Domains of the Field. Association for Educational Communication and Technology: Washington, DC.

Hamalik Oemar. 2008. Proses Belajar Mengajar. Jakarta: Bumi Aksara.

Pribadi. B. A. 2017. Media dan Teknologi Dalam Pembelajaran. Jakarta: Kencana

Prastowo, A. 2018. Sumber Belajar dan Pusat Sumber belajar; Teori dan Aplikasinya di Sekolah/Madrasyah. Jakarta: PrenamediaGroup

Sitepu, B.P. 2017. Pengembangan Sumber belajar. Jakarta: PT. Raja Grafindo Persada.

Sugiyono. 2017. Metode penelitian Kuntitatif, kualitatif dan R\&D: Bandung: Alfabeta CV

Yaumi, M. 2018. Media dan Teknologi Pembelajaran. Jakarta: Prenadamedia

Arief S. Sadiman, et al. 2007. Media Pendidikan, (Jakarta : PT. Raja Grafindo Persada.

Azhar $\quad$ Arsyad, 2000. Media Pengajaran, Jakarta: Raja Grafindo Persada.

2003. Media Pembelajaran, Jakarta: Departemen Pendidikan Nasional Direktorat Jenderal Pendidikan Dasar dan Menengah Direktorat Tenaga Kependidikan.

Hamalik oemar, 1989. Media Pendidikan. Bandung. PT. Citra Aditya Bakti.

Pribadi. B. A. 2017. Media dan Teknologi Dalam Pembelajaran. Jakarta: Kencana

Prastowo, A. 2018. Sumber Belajar dan Pusat Sumber belajar; Teori dan Aplikasinya di Sekolah/Madrasyah. Jakarta: PrenamediaGroup 